\title{
PENGARUH JUMLAH PERSEDIAAN BAHAN BAKU DAN KAPASITAS MESIN TERHADAP VOLUME PRODUKSI PADA UD. CAHAYA RESTU KOTA PROBOLINGGO
}

\author{
Dedi Joko Hermawan \\ Fakultas Ekonomi, Universitas Panca Marga Probolinggo, Indonesia \\ Email: dedijoko@gmail.com
}

\begin{abstract}
The objective of this study was for determine and analyze the effect of the amount of raw material inventory and engine capacity simultaneously to volume production at UD. Cahaya Restu. The population of this research is all company data on the number of inventories of raw materials, machine capacity and production volume in 2011-2016 at UD.Cahaya Restu. The collection of data through observation. The data used in this research is secondary data in the form of a company's internal data UD. Cahaya Restu, Based on the results of multiple regression analysis and hypothesis testing by using test of $F$ can be seen that simultaneously the number of inventories of raw materials (XI) and engine capacity (X2) significantly affects the volume of production (Y). While based on the hypothesis test by using test tcount that the partial amount of raw material inventory (X1) there is a significant effect on the volume of production $(Y)$ and the capacity of the machine (X2) partially no significant effect on the volume of production $(Y)$.
\end{abstract}

Keywords: the number of inventories of raw materials, machine capacity, and volume production

\begin{abstract}
ABSTRAK
Tujuan diadakannya penelitian ini adalah untuk mengetahui dan menganalisis pengaruh jumlah persediaan bahan baku dan kapasitas mesin secara simultan terhadap volume produksi pada UD. Cahaya Restu dan untuk mengetahui dan menganalisis pengaruh jumlah persediaan bahan baku dan kapasitas mesin secara parsial terhadap volume produksi pada UD. Cahaya Restu. Populasi penelitian ini adalah seluruh data perusahaan yang mengenai jumlah persediaan bahan baku, kapasitas mesin dan volume produksi tahun 2011-2016 pada UD. Cahaya Restu. Berdasarkan hasil analisis regresi linier berganda dan uji hipotesis dengan menggunakan uji $\mathrm{F}_{\text {hitung }}$ dapat diketahui bahwa secara simultan jumlah persediaan bahan baku $\left(\mathrm{X}_{1}\right)$ dan kapasitas mesin $\left(\mathrm{X}_{2}\right)$ berpengaruh signifikan terhadap volume produksi (Y). Sedangkan berdasarkan hasil uji hipotesis dengan menggunakan uji $t_{\text {hitung }}$ bahwa secara parsial jumlah persediaan bahan baku $\left(\mathrm{X}_{1}\right)$ terdapat pengaruh signifikan terhadap volume produksi $(\mathrm{Y})$ dan Kapasitas mesin $\left(\mathrm{X}_{2}\right)$ secara parsial tidak terdapat pengaruh signifikan terhadap volume produksi (Y).
\end{abstract}

Kata kunci: jumlah persediaan bahan baku, kapasitas mesin, dan volume produksi 


\section{PENDAHULUAN}

Memasuki era pasar bebas yang sudah di depan mata, memaksa para pemilik perusahaan atau pabrik untuk tetap survive dalam bersaing dengan perusahaan lain dalam mengandalkan produk yang dihasilkan. Tuntutan kebutuhan konsumen yang kian hari kian bertambah jumlah maupun macamnya juga merupakan hal yang membuat perusahaanperusahaan tersebut berusaha semaksimalkan mungkin memenuhi segala tuntutan itu dengan tetap menekankan prinsip efektifitas dan efisiensi.

Agar sukses dalam menciptakan suatu produk maka setiap perusahaan harus dapat menetapkan strategi manajemen produksi dan operasi yang di dalamnya merupakan kegiatan mengatur dan mengkoordinasikan alat dan sumber daya-sumber daya yang berupa sumber daya manusia, sumber daya alat, sumber daya biaya dan bahan secara efisien dan efektif untuk menciptakan dan menambah nilai kegunaan (utility) suatu barang dan jasa.

Menurut Sofjan Assauri (2004) suatu produk didasarkan oleh ukuran dan karakteristik dari produk yang diproduksi sesuai dengan ketinggian konsumen. Keinginan atau selera antar pembeli juga berbeda mungkin dikarenakan perbedaan sifat daerah asalnya, tingkat sosialnya ataupun sebab lainnya. Akibat kenyataan ini menyulitkan bagi perusahaan, faktor-faktor yang menyebabkan suatu produk tidak sesuai dengan apa yang diharapkan, disebakan oleh bahan baku, tenaga kerja, kinerja mesin.

Bila dilihat dari kegiatan atau proses produksi maka akan terlihat masalah utama dalam proses produksi adalah tersedianya bahan baku. Pada dasarnya persediaan mempermudah dan memperlancar jalannya operasi suatu perusahaan yang harus dilakukan secara berturut-turut dalam memproduksi barang serta menyampaikan kepada konsumen. Setiap perusahaan baik perusahaan industri maupun perusahaan dagang selalu mempunyai persediaan bahan baku yang memadai agar dapat memperlancar jalannya suatu proses produksi.

Setiap perusahaan yang memproduksi suatu produk jadi pasti 
membutuhkan bahan baku, dimana bahan baku merupakan suatu kebutuhan pokok dalam memproduksi barang dan harus ada pada saat dibutuhkan. Guna menghindari kemacetan dalam kegiatan produksi, perlu adanya sejumlah persediaan bahan baku yang cukup, dengan demikian pelaksanaan proses produksi dapat berjalan dengan lancar tanpa ada hambatan dalam hal bahan baku. Namun hal ini tidak berarti perusahaan harus menyediakan bahan baku yang berlebihan agar terjaminnya proses produksi, sebab jika persediaan berlebihan maka akan mengakibatkan tertanamnya modal secara tidak produktif yang juga mengakibatkan kerugian. Oleh karena itu perusahaan memerlukan bahan baku dengan kualitas yang terjamin dan cukup untuk proses produksi yang telah direncanakan. Persediaan bahan baku yang dilakukan oleh UD. Cahaya Restu cenderung stabil, bahan baku diperoleh dari daerah Bandung, sehingga pengirimannya pun tidak membutuhkan waktu yang lama, hanya membutuhkan waktu sekitar 2-3 hari.

Selain bahan baku yang mempengaruhi kelancaran jalannya proses produksi adalah kapasitas mesin. Besarnya jumlah kapasitas produksi juga tidak lepas dari kapasitas mesin yang digunakan untuk proses produksi untuk dapat menghasilkan produk yang maksimal. hal ini semakin banyak kapasitas produksinya tentunya membutuhkan kapasitas mesin yang efektif dan efisien untuk proses produksi yang tidak sedikit jumlahnya. Mesin yang digunakan di UD. Cahaya Restu menggunakan mesin jahit yang pengoperasiannya menggunakan tenaga manusia sehingga proses pengerjaan membutuhkan waktu yang cukup lama sehingga kapasitas mesin yang di dapat bisa dikatakan belum efisien dan efektif. kapasitas mesin yang diharapkan oleh UD. Cahaya Restu sendiri sekitar 550 jam per bulannya. Tetapi pada kenyataannya kapasitas mesin yang dihasilkan masih jauh dari harapan perusahaan sebenarnya.

Dengan melihat permasalahan tersebut di atas, maka penulis tertarik untuk mengambil judul "Pengaruh Jumlah Persediaan Bahan Baku dan Kapasitas Mesin Terhadap Volume Produksi pada UD. Cahaya Restu" 
Adapun tujuan diadakannya penelitian terhadap masalah tersebut adalah:

1. Untuk mengetahui dan menganalisis pengaruh jumlah persediaan bahan baku dan kapasitas mesin secara simultan terhadap volume produksi pada UD. Cahaya Restu.

2. Untuk mengetahui dan menganalisis pengaruh jumlah persediaan bahan baku dan kapasitas mesin secara parsial terhadap volume produksi pada UD. Cahaya Restu.

\section{LITERATUR}

\section{Persediaan Bahan Baku}

Menurut Prawirosentono (dalam Ramdhani, 2014: 374), "Persediaan adalah aktiva lancar yang terdapat di perusahaan dalam bentuk persediaan bahan mentah (bahan baku, bahan setengah jadi, dan barang jadi)"'.

Menurut Ramdhani (2014: 374), "Persediaan adalah bagian utama dari modal kerja dan aktiva yang setiap saat mengalami perubahan.dapat disimpulkan bahwa persediaan adalah suatu aktiva yang harus tersedia di perusahaan pada saat diperlukan untuk menjamin kelancaran dalam menjalankan perusahaan".

\section{Bahan Baku}

Menurut Smith, Jay M. (dalam Ramdhani, 2014: 368), "Bahan baku yang secara langsung digunaan dalam produksi barangbarang tertentu disebut bahan langsung, sedangkan bahan pembantu pabrik disebut bahan tidak langsung".

Menurut Ramdhani (2014: 368), "Bahan baku merupakan barang-barang yang diperoleh untuk digunakan dalam proses produksi. Beberapa bahan baku diperoleh secara langsung dari sumber-sumber alam. Bahan baku juga dapat diperoleh dari perusahaan lain.

\section{Mesin}

Menurut Sofjan Assauri (dalam Astutik (2014:37)) Mesin adalah suatu peralatan yang digerakkan oleh suatu kekuatan atau tenaga yang digunakan untuk membantu manusia dalam mengerjakan produk atau bagian-bagian produk tertentu.

Peranan mesin menurut Sofjan Assauri dalam Astutik (2014:37) mengemukakan bahwa mesin sangat- 
lah membantu manusia dalam melakukan pengerjaan produksi suatu barang sehingga barang yang dihasilkan dalam waktu lebih pendek, jumlah lebih banyak dan kualitas lebih baik.

\section{Kapasitas Mesin}

McNair C.J dan Vangermeersch dalam Astutik (2014:37) mendefinisikan kapasitas sebagai kemampuan dari suatu organisasi atau perusahaan untuk menciptakan nilai dimana kemampuan tersebut didapatkan dari berbagai jenis sumber daya yang dimiliki oleh perusahaan.

Definisi kapasitas menurut Hilton, Maher dan Selto dalam Astutik (2014:38) merupakan ukuran dari kemampuan proses produksi dalam mengubah sumber daya yang dimiliki menjadi suatu produk atau jasa yang akan digunakan oleh konsumen.

\section{Volume Produksi}

Volume produksi atau yang biasa juga disebut hasil produksi adalah suatu barang yang dihasilkan melalui serangkaian kegiatan dalam proses produksi. Barang dan jasa yang dihasilkan selanjutnya dikemas untuk disalurkan kepada konsumen. Volume produksi juga merupakan output atau keluaran hasil dari proses produksi yang dilakukan berupa barang atau jasa yang berguna bagi masyarakat sesuai dengan fungsi dan kegunaannya.

Menurut Indriyo dalam Astutik (2014:38) Volume Produksi adalah interaksi antara bahan dasar, bahan pembantu, tenaga kerja dan mesin-mesin serta alat-alat perlengkapannya yang dipergunakan. Menurut T. Hani Handoko (2000:128), faktor-faktor yang dipertimbangkan dalam proses produksi atau faktorfaktor yang mempengaruhi pelaksanaan proses produksi untuk mencapai volume produksi adalah sebagai berikut:

a. Kebutuhan Modal

Modal merupakan faktor yang sangat penting dalam menentukan volume produksi. Besar kecilnya usaha atau lancar tidaknya proses produksi sangat tergantung pada modal yang tersedia. Dan modal dibutuhkan untuk menyediakan berbagai persediaan, mesin-mesin dan modal digunakan untuk membiayai proses produksi. 
b. Kondisi Pasar

Meskipun modal banyak, bahan baku tersedia, tenaga kerja ada dan kapasitas mesin mencukupi, tetapi permintaan akan produk yang dihasilkan tidak diterima oleh pasar, maka produk yang dihasilkan akan menumpuk, sehingga proses produksi tidak dapat berjalan secara optimal, karena produk yang dihasilkan tidak dapat dijual.

c. Tersedianya Bahan Baku

Bahan baku merupakan faktor yang sangat penting bagi perusahaan, tanpa bahan baku maka prossesing perusahaan akan mengalami kemacetan. Dengan demikian tersedianya bahan baku yang terbatas tentunya akan menghambat jalannya proses produksi.

\section{d. Tenaga Kerja}

Tenaga kerja merupakan faktor yang tidak boleh dilupakan terutama pada perusahaan yang tidak menggunakan mesin dalam proses produksinya, dimana tenaga kerja manusia tentunya secara otomatis berpengaruh terhadap proses produksi, karena banyak tidaknya jumlah tenaga kerja yang dimiliki oleh perusahaan merupakan kemampuan perusahaan dalam menghasilkan produksi perusahaan yang bersangkutan.

e. Kapasitas Mesin atau Teknologi yang Dimiliki

Perusahaan harus mempertimbangkan kapasitas mesin atau kemajuan teknologi untuk proses produksi. Suatu perusahaan tidak mungkin berproduksi melebihi kemampuan kapasitas mesin yang dimiliki. Karena kapasitas mesin ini merupakan batasan untuk menghasilkan sejumlah produk perusahaan. Kapasitas mesin atau teknologi dapat mendukung proses produk agar tetap stabil selama periode waktu tertentu.

\section{Hipotesis}

Kegiatan produksi akan terwujud dan terlaksana tersedianya alat atau benda yang akan digunakan untuk memproduksi suatu barang. Jadi adanya faktor-faktor produksi sangat diperlukan untuk menciptakan, menghasilkan benda atau jasa dalam suatu perusahaan. Adapun faktor produksi yang dimaksud ada- 
lah: Faktor persediaan bahan baku dan faktor kapasitas mesin.

Kerangka pemikiran dalam penelitian ini adalah sebagai berikut :

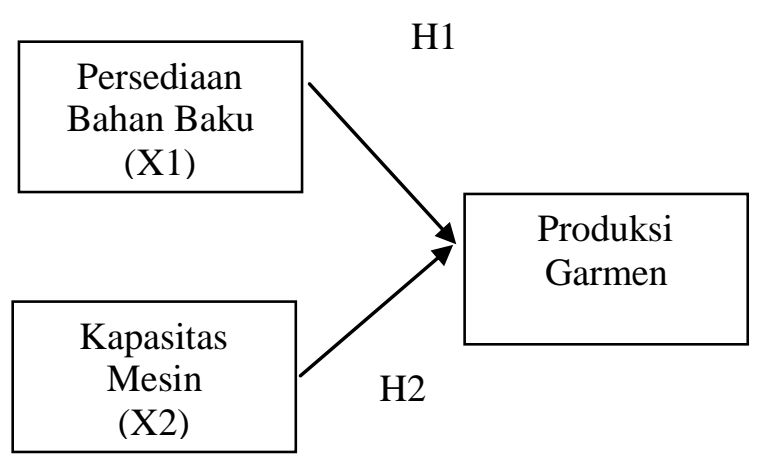

\section{Gambar 1. Kerangka Pemikiran Teoritis}

Hipotesis yang diajukan dalam penelitian ini adalah sebagai berikut :

Hipotesis pertama yang diajukan adalah untuk mengetahui pengaruh jumlah persediaan bahan baku terhadap volume produksi garmen adalah sebagai berikut:

$\mathrm{H}_{\mathrm{o}}: \quad \beta_{1}=0$, artinya tidak ada pengaruh positif dan signifikan antara bahan baku terhadap produksi garmen.

$\mathrm{H}_{1}: \beta_{1}>0$, artinya ada pengaruh positif dan signifikan antara bahan baku terhadap produksi garmen.

Hipotesis kedua yang diajukan adalah untuk mengetahui pengaruh kapasitas mesin terhadap produksi garmen di Kota Probolinggo adalah sebagai berikut:

$\mathrm{H}_{\mathrm{o}}: \quad \beta_{2}=0$, artinya tidak ada pengaruh positif dan signifikan antara kapasitas mesin terhadap produksi garmen.

$\mathrm{H}_{1}: \beta_{2}>0$, artinya ada pengaruh positif dan signifikan antara kapasitas mesin terhadap produksi garmen.

\section{METODOLOGI PENELITIAN}

\section{Jenis dan Sumber Data}

Dalam penyusunan penulisan penelitian ini, penulis menggunakan jenis penelitian kuantitatif dengan pendekatan deskriptif. yaitu penjabaran hasil pengolahan data yang berbentuk angka untuk memberikan kejelasan suatu konsep analisis mengenai persediaan bahan baku dan kapasitas mesin terhadap volume produksi pada UD. Cahaya Restu Kota Probolinggo. Sumber data yang digunakan dalam penelitian adalah sumber data sekunder yang berupa data persediaan bahan baku, kapasitas mesin dan volume produksi dari perusahaan UD. Cahaya Restu. 


\section{Populasi dan Sampel}

Populasi adalah suatu kesatuan individu atau subyek pada wilayah dan waktu serta dengan kualitas tertentu yang akan diamati/ diteliti (Supardi 2005:101). Populasi penelitian ini adalah seluruh data perusahaan yang mengenai jumlah persediaan bahan baku, kapasitas mesin dan volume produksi tahun 20112016 pada UD. Cahaya Restu. Sedangkan Sampel adalah bagian dari populasi yang dijadikan subjek penelitian sebagai "wakil" dari para anggota populasi (Supardi 2005: 103). Sampel yang diambil dalam penelitian ini adalah komponen-komponen yang berupa jumlah persediaan bahan baku, kapasitas mesin, dan volume produksi pada UD. Cahaya Restu dengan satuan waktunya perbulan selama 36 bulan pada tahun 2013 sampai dengan tahun 2015.

\section{Metode Pengumpulan data}

Metode pengumpulan data dalam penelitian ini menggunakan metode Observasi. Observasi adalah kegiatan pengamatan yang lebih menekankan pada proses pengamatan di mana selanjutnya pengamatan terse- but ditindaklanjuti dengan pencatatan data secara cermat dan sistematis serta dokumentasi yang baik (Santosa 2007:13).

\section{Definisi Operasional Variabel}

Variabel-variabel yang digunakan dalam penelitian ini adalah:

a. Persediaan Bahan Baku ( $\left.\mathrm{X}_{1}\right)$

Adalah banyaknya bahan baku yang dipergunakan oleh UD. Cahaya Restu dalam operasional produksi setiap bulan untuk melakukan aktifitas merubah bahan mentah menjadi barang jadi atau siap pakai. Cara pengukurannya berdasarkan jumlah pemakaian bahan baku setiap bulannya adalah kg (kilogram) perbulan.

b. Kapasitas mesin $\left(\mathrm{X}_{2}\right)$

Adalah banyaknya kapasitas mesin yang dipergunakan oleh UD. Cahaya Restu dalam rangka mengolah bahan baku menjadi produk jadi. Variabel ini diukur dalam satuan jam perbulan.

c. Volume Produksi (Y)

Adalah hasil akhir dari keseluruhan proses produksi yang dilakukan oleh UD. Cahaya Restu, dalam hal ini yaitu realisasi produksi. Data yang dianalisis 
adalah berdasarkan realisasi produksi yaitu total atau seluruh jumlah produk yang dihasilkan perusahaan per bulan.

\section{Metode Analisis Data}

\section{Uji Validitas}

Uji Validitas Item atau butir dapat dilakukan dengan menggunakan software SPSS. Untuk proses ini, akan digunakan Uji Korelasi Pearson Product Moment. Dalam uji ini, setiap item akan diuji relasinya dengan skor total variabel yang dimaksud. Dalam hal ini masing-masing item yang ada di dalam variabel $\mathrm{X}$ dan $\mathrm{Y}$ akan diuji relasinya dengan skor total variabel tersebut. Agar penelitian ini lebih teliti, sebuah item sebaiknya memiliki korelasi (r) dengan skor total masing-masing variabel $\geq 0,25$. Item yang punya $r$ hitung $<0,25$ akan disingkirkan akibat mereka tidak melakukan pengukuran secara sama dengan yang dimaksud oleh skor total skala dan lebih jauh lagi, tidak memiliki kontribusi dengan pengukuran seseorang jika bukan malah mengacaukan.

\section{Uji Reliabilitas}

Uji Reliabilitas dilakukan dengan uji Alpha Cronbach. Jika nilai alpha $>0,7$ artinya reliabilitas mencukupi (sufficient reliability) sementara jika alpha $>0,80$ ini mensugestikan seluruh item reliabel dan seluruh tes secara konsisten secara internal karena memiliki reliabilitas yang kuat.

\section{Uji Asumsi Klasik}

Pengujian ini dimaksudkan untuk mendeteksi ada tidaknya normalitas, multikolinieritas, heteroskedastisitas dan autokorelasi dalam hasil estimasi, karena apabila terjadi penyimpangan terhadap asumsi klasik tersebut, uji $\mathrm{F}$ dan uji $\mathrm{t}$ yang dilakukan menjadi tidak valid dan secara statistik dapat mengacaukan kesimpulan yang diperoleh.

\section{Uji Normalitas}

Uji normalitas bertujuan untuk menguji apakah dalam model regresi, dependen variabel dan independen variabel keduanya mempunyai distribusi normal ataukah tidak. Jika data menyebar di sekitar garis diagonal dan mengikuti arah garis diagonal, atau grafik histogramnya menunjukkan pola distribusi normal, maka model regresi me- 
menuhi asumsi normalitas dan sebaliknya.

2. Uji Multikolinieritas

Metode ini digunakan untuk mendeteksi ada atau tidaknya multiko-linearitas, maka digunakan rumus Varian Inflation Faktor ( VIF ) yang merupakan kebalikan dari toleransi. Asumsi multikolinearitas terpenuhi jika nilai VIF pada Output SPSS dibawah 10 dan memiliki nilai positif. Karena $\mathrm{VIF}=1 /$ Tolerance, maka bebas multikolinearitas juga dapat ditentukan jika nilai tolerance diatas 0,10 .

3. Uji Autokorelasi

Autokorelasi bertujuan untuk menguji apakah dalam sebuah model regresi linear ada korelasi antara kesalahan pengganggu pada periode $t$, jika ada berarti autokorelasi. Dalam penelitian keberadaan autokorelasi diuji dengan uji Durbin Watson (DW test).

Pengambilan keputusan :

a. Jika angka Durbin Watson $(D W)$ dibawah -2 berarti terdapat autokorelasi positif b. Jika angka Durbin Watson $(D W)$ diantara -2 sampai +2 berarti tidak ada autokorelas

c. Jika angka Durbin Watson $(D W)$ diatas +2 berarti terdapat autokorelasi negatif.

4. Persamaan Regresi

Analisis yang digunakan adalah analisis regresi. Untuk mengetahui pengaruh variabel persediaan bahan baku (X1) dan kapasitas mesin (X2) terhadap volume produksi (Y) pada UD. Cahaya Restu Kota Probolinggo digunakan persamaan regresi. Adapun bentuk persamaan regresi linear berganda yang digunakan dapat dirumuskan (Sudarmanto, 2005:160)

$\mathrm{Y}=\mathrm{a}+\beta_{1} \mathrm{X}_{1}+\beta_{2} \mathrm{X}_{2}+\mathrm{e}$

Dimana :

$\mathrm{Y}=$ Volume Produksi

$\mathrm{X}_{1}=$ Jumlah Persediaan Bahan Baku

$\mathrm{X}_{2} \quad$ Kapasitas mesin

$\mathrm{a}=$ Konstanta

$\beta_{1} \beta_{2}=$ Koefesien regresi untuk variabel

$\mathrm{e}=$ Faktor pengganggu atau standar eror

Pengujian hipotesis pada penelitian ini adalah sebagai berikut: 
Uji F

Untuk mengetahui ada atau tidaknya pengaruh antara variabel bebas dan variabel terikat atau pengaruh Jumlah Persediaan Bahan Baku $\left(\mathrm{X}_{1}\right)$, dan Kapasitas mesin $\left(\mathrm{X}_{2}\right)$ terhadap volume produksi (Y) secara simultan digunakan uji F.

Uji t

Untuk pengujian terhadap koefisien regresi secara parsial menggunakan uji t ialah untuk mengetahui pengaruh jumlah persediaan bahan baku dan kapasitas mesin secara sendiri-sendiri atau secara parsial terhadap volume produksi.

\section{HASIL ANALISIS DAN PEMBA-}

\section{HASAN}

\section{Deskripsi Data}

Seperti yang digambarkan pada Tabel 1 di bawah yang menunjukkan bahwa jumlah persediaan bahan baku terendah terjadi pada tahun 2013 pada bulan Februari yaitu sebesar 45.720 meter dan yang tertinggi terjadi pada tahun 2014 pada bulan Juni sebesar 64.000 meter.

Seperti pada Tabel yang menunjukkan bahwa kapasitas mesin terendah terjadi pada tahun 2013 pada bulan Februari yaitu sebesar 212 jam dan yang tertinggi terjadi pada tahun 2014 pada bulan Juli yaitu sebesar 330 jam.

Tabel 1

Persediaan Bahan Baku

UD. Cahaya Restu

\begin{tabular}{|c|c|c|c|}
\hline \multirow{2}{*}{ Bulan } & \multicolumn{3}{|c|}{ Persediaan Bahan Baku (m) } \\
\cline { 2 - 4 } & 2013 & 2014 & 2015 \\
\hline Januari & 54.500 & 56.300 & 58.500 \\
\hline Februari & 45.720 & 49.500 & 50.500 \\
\hline Maret & 53.400 & 53.400 & 52.000 \\
\hline April & 53.400 & 54.000 & 58.600 \\
\hline Mei & 52.200 & 52.200 & 54.000 \\
\hline Juni & 61.700 & 64.000 & 59.000 \\
\hline Juli & 57.800 & 58.700 & 54.500 \\
\hline Agustus & 49.500 & 56.500 & 53.100 \\
\hline September & 48.600 & 51.200 & 52.100 \\
\hline Oktober & 52.300 & 53.600 & 55.000 \\
\hline November & 56.200 & 52.000 & 54.500 \\
\hline Desember & 52.500 & 50.000 & 53.000 \\
\hline
\end{tabular}

Sumber data : Data Sekunder 2016

Tabel 2

Kapasitas Mesin UD. Cahaya Restu

\begin{tabular}{|c|c|c|c|}
\hline \multirow{2}{*}{ Bulan } & \multicolumn{3}{|c|}{ Kapasitas mesin (jam) } \\
\cline { 2 - 4 } & 2013 & 2014 & 2015 \\
\hline Januari & 248 & 248 & 248 \\
\hline Februari & 212 & 224 & 224 \\
\hline Maret & 220 & 248 & 248 \\
\hline April & 230 & 248 & 248 \\
\hline Mei & 248 & 230 & 248 \\
\hline Juni & 290 & 310 & 325 \\
\hline Juli & 290 & 330 & 325 \\
\hline Agustus & 248 & 248 & 248 \\
\hline September & 248 & 248 & 248 \\
\hline Oktober & 248 & 248 & 248 \\
\hline November & 248 & 248 & 248 \\
\hline Desember & 220 & 220 & 220 \\
\hline
\end{tabular}

Sumber data : Data Sekunder 2016 
Tabel 3

Volume Produksi UD. Cahaya Restu

\begin{tabular}{|c|c|c|c|}
\hline \multirow{2}{*}{ Bulan } & \multicolumn{3}{|c|}{ Volume Produksi } \\
\cline { 2 - 4 } & 2013 & 2014 & 2015 \\
\hline Januari & 34.500 & 46.300 & 48.500 \\
\hline Februari & 25.600 & 39.500 & 30.500 \\
\hline Maret & 33.600 & 33.400 & 42.000 \\
\hline April & 33.600 & 34.000 & 48.600 \\
\hline Mei & 42.200 & 42.200 & 34.000 \\
\hline Juni & 51.500 & 44.000 & 39.000 \\
\hline Juli & 47.800 & 48.700 & 44.500 \\
\hline Agustus & 39.500 & 36.500 & 43.100 \\
\hline September & 28.600 & 41.200 & 42.100 \\
\hline Oktober & 32.300 & 43.600 & 45.000 \\
\hline November & 36.200 & 32.000 & 34.500 \\
\hline Desember & 32.500 & 30.000 & 33.000 \\
\hline
\end{tabular}

Sumber data : Data Sekunder 2016

Seperti pada tabel diatas yang menunjukkan bahwa volume produksi terendah terjadi pada tahun 2013 pada bulan Februari yaitu sebesar 25.600 meter sedangkan tertinggi terjadi pada tahun 2014 pada bulan Juli yaitu sebesar 48.700 meter.

\section{Analisis Data}

Uji Validitas

Dalam penelitian ini, terlihat bahwa variabel persediaan bahan baku memiliki nilai Corrected ItemTotal Correlation / nilai korelasi sebesar 0,965 sedangkan variabel kapasitas mesin memiliki nilai Corrected Item-Total Correlation / nilai korelasi sebesar 0,813 dan variabel volume produksi memiliki nilai Corrected
Item-Total Correlation/ nilai korelasi sebesar 0,964. Masing-masing variabel diatas memiliki nilai korelasi (r) $>0,25$. Itu berarti masing-masing variabel diatas telah valid.

Uji Realibilitas

Uji Reliabilitas dilakukan dengan uji Alpha Cronbach. Dari penelitian ini terlihat bahwa memiliki nilai Alpha Cronbach sebesar 0,951. Artinya alpha $>0,90$ maka reliabilitas sempurna. Ini berarti seluruh item reliabel karena memiliki reliabilitas yang kuat.

\section{Uji Asumsi Klasik}

1. Uji Normalitas

Berdasarkan uji normalitas dengan melihat penyebaran data (titik) pada sumbu diagonal dari grafik normal P-P Plot terlihat bahwa data menyebar di sekitar garis diagonal dan mengikuti arah garis diagonal, atau grafik histogramnya menunjukkan pola distribusi normal, maka dapat dikatakan bahwa regresi berdistribusi normal. Maka asumsi normalitas terpenuhi. 
2. Uji Multikolinieritas

Dari perhitungan uji multikolinieritas dapat diketahui bahwa nilai VIF dari variabel $\mathrm{Ju}$ mlah Persediaan Bahan Baku $\left(\mathrm{X}_{1}\right)$ sebesar 1,854 dan nilai $\mathrm{VIF}$ dari variabel Kapasitas mesin $\left(\mathrm{X}_{2}\right)$ sebesar 1,854 , itu berarti nilai VIF dari semua variabel bebas jauh di bawah 10 sehingga dapat disimpulkan dalam data tidak terjadi penyimpangan asumsi klasik Multikolinieritas.

3. Uji Autokorelasi

Pengujian ada atau tidaknya auto-korelasi dalam persamaan regresi ini dapat dilakukan dengan melihat keadaan nilai Durbin Watson (DW test) dari hasil perhitungan. Uji autokorelasi dilakukan dengan uji Durbin Watson (DW). Dari regresi diperoleh angka Durbin Watson sebesar 1,858 karena angka Durbin Watson $(D W)$ diantara -2 sampai +2 maka model dapat dikatakan tidak mengandung gejala autokorelasi.

4. Uji Regresi Linier Berganda

Berdasarkan hasil perhitungan diperoleh persamaan regresi linier berganda sebagai berikut :
$\mathrm{Y}=\beta_{1} \mathrm{X} 1+\beta_{2} \mathrm{X} 2+\mathrm{e}$

$\mathrm{Y}=0,507 \mathrm{X}_{1}+0,219 \mathrm{X}_{2}+\mathrm{e}$

Interprestasi dari model regresi diatas adalah sebagai berikut :

1. Koefisien regresi untuk $X_{1}\left(b_{1}\right)=$ 0,507. Artinya jika Jumlah Persediaan Bahan Baku $\left(\mathrm{X}_{1}\right)$ naik 1 meter (m) maka jumlah Volume Produksi (Y) akan naik 0,507 meter (m) dengan asumsi variabel Kapasitas mesin $\left(\mathrm{X}_{2}\right)$ adalah konstan.

2. Koefisien regresi untuk $X_{2}\left(b_{2}\right)=$ 0,219. Artinya jika Kapasitas mesin $\left(\mathrm{X}_{2}\right)$ naik 1 jam maka jumlah Volume Produksi (Y) akan naik sebanyak 0,219 meter (m) dengan asumsi jumlah persediaan bahan baku $\left(\mathrm{X}_{1}\right)$, kapasitas mesin $\left(\mathrm{X}_{2}\right)$ adalah konstan.

3. Nilai e menunjukkan faktor pengganggu di luar model yang diteliti. Nilai koefisien determinasi atau $\mathrm{R}^{2}$ digunakan untuk mengukur seberapa jauh kemampuan model dalam menerangkan variasi variabel terikat. Hasil dari perhitungan diperoleh nilai $\mathrm{R}^{2}$ sebesar 0,457 yang berarti $45,7 \%$ variasi produksi garmen dapat dijelaskan oleh va- 
riabel-variabel bebas (persediaan

bahan baku dan kapasitas me$\sin$ ), dan sekitar $54,3 \%$ dijelaskan variabel lain di luar model.

\section{Uji F}

Secara bersama-sama/ serentak (uji F) variabel bebas yang terdiri dari persediaan bahan baku dan kapasitas mesin mempunyai pengaruh yang signifikan terhadap variabel produksi garmen pada tingkat kepercayaan sampai dengan $\alpha$ $=5 \%$. Hal ini dapat dilihat nilai Probabilitas Sig sebesar 0,000 lebih kecil dari 0,05 dan nilai $\mathrm{F}$ hitung sebesar 13,863 lebih besar dari $\mathrm{F}$ tabel yang sebesar 3,28. Dengan demikian hipotesis $\mathrm{H}_{1}$ yang menyatakan semua variabel bebas mempengaruhi variabel tak bebas secara bersama-sama, dapat diterima atau hipotesis nol $\left(\mathrm{H}_{0}\right)$ yang menyatakan semua variabel bebas tidak mempengaruhi variabel terikat (produksi garmen) ditolak. Artinya variabel-variabel persediaan bahan baku dan kapasitas mesin sangat dapat dipercaya mempengaruhi variabel produksi garmen.
Uji t

Secara parsial (masing-masing variabel bebas), variabel X1 (variabel persediaan bahan baku) berpengaruh signifikan terhadap volume produksi garmen, hal ini bisa dilihat dari nilai Prob. Sig sebesar 0,007 yang lebih kecil dari $0,05(\alpha=5 \%)$ dan nilai t hitung sebesar 2,904 lebih besar dari t tabel sebesar 2,034 dengan demikian hipotesis yang menyatakan persediaan bahan baku berpengaruh terhadap produksi garmen diterima.

Sedangkan untuk variabel X2 (variabel kapasitas mesin) tidak berpengaruh signifikan terhadap volume produksi garmen, hal ini bisa dilihat dari nilai Pro. Sig Sebesar 0,218 lebih besar dari $0,05(\alpha=5 \%)$ dan nilai $\mathrm{t}$ hitung sebesar 1,256 lebih kecil dari $\mathrm{t}$ tabel sebesar 2,034 artinya hipotesis yang menyatakan kapasitas mesin berpengaruh terhadap produksi garmen ditolak.

Pembahasan

a. Pengaruh Jumlah Persediaan Bahan Baku Terhadap Volume Produksi

Dengan menggunakan tingkat signifikansi $5 \%$ dapat dilihat 
bahwa bahan baku berpengaruh secara signifikan dan bertanda positif terhadap produksi garmen. Tanda positif menunjukkan bahwa apabila bahan baku tersedia sebesar 1 meter (m), maka produksi garmenpun meningkat sebesar 0,507 m. Bahan baku yang digunakan untuk sekali produksi paling banyak adalah sebanyak 64.000 meter perbulannya dengan menggunakan jenis kain local dan rata-rata bahan baku yang diperoleh berasal dari pasar sedangkan untuk produsen dengan skala besar memperoleh bahan baku dari distributor karena membutuhkan bahan baku dalam jumlah besar.

Adanya pengaruh bahan baku terhadap produksi garmen menandakan bahwa dalam usaha konveksi seperti ini sangat tergantung dari bahan baku yang tersedia. Bahan baku merupakan bahan dasar utama yang digunakan untuk memproduksi garmen, apabila bahan baku kurang tersedia, maka akan berdampak pada terhambatnya produksi garmen yang akan dihasilkan oleh produsen. Hasil penelitian ini se- suai dengan teori yang dikemukakan oleh Handoko (2000) dan didukung dengan penelitian yang dilakukan oleh Karmini dan Istanti (2016) yang menyimpulkan bahwa Jumlah Persediaan Bahan Baku berpengaruh positif terhadap Volume Produksi.

\section{b. Pengaruh Kapasitas mesin \\ Terhadap Volume Produksi}

Hasil uji hipotesis menunjukan bahwa secara parsial kapasitas mesin tidak berpengaruh signifikan terhadap volume produksi. Hasil uji dilihat dari nilai ( $\mathrm{t}_{\text {hitung }}=$ $\left.1,256<\mathrm{t}_{\text {tabel }}=2,034\right)$. Hal ini disebabkan adanya masa mesin aus dan mesin-mesinnya yang sudah tua. Selain itu kinerja dari mesin pabrik itu juga rendah dan kurang produktif. Hasil penelitian ini tidak sesuai dengan teori yang dikemukakan oleh Handoko (2000), karena menurut Handoko (2000) kapasitas mesin berpengaruh terhadap volume produksi. Akan tetapi penelitian yang dilakukan oleh Astutik (2014) menyimpulkan bahwa jumlah kappasitas mesin tidak berpengaruh signifikan terhadap volume produksi. 
KESIMPULAN DAN SARAN

\section{Kesimpulan}

Berdasarkan analisis dan pembahasan, maka kesimpulan yang dapat diambil adalah sebagai berikut :

1. Secara simultan dengan menggunakan hasil uji $\mathrm{F}$ menunjukkan bahwa jumlah persediaan bahan baku dan kapasitas mesin berpengaruh terhadap volume produksi pada UD. Cahaya Restu Kota Probolinggo.

2. Secara parsial dengan menggunakan hasil uji t menunjukkan :

a. Jumlah persediaan bahan baku secara parsial berpengaruh signifikan terhadap volume produksi, dikarenakan banyaknya bahan baku mempengaruhi volume produksi. Jika bahan baku cukup tersedia maka produk yang dihasilkan juga cukup. Namun jika sarana pengelolahan tidak baik, maka jumlah volume produksi akan menurun.

b. Kapasitas mesin secara parsial tidak berpengaruh signifikan terhadap volume produksi, hal ini disebabkan adanya masa mesin aus dan mesin-mesinnya yang sudah tua.

\section{Keterbatasan Penelitian}

1. Keterbatasan baik tenaga dan waktu yang terlalu singkat sehingga penelitian ini terhambat.

2. Keterbatasan dalam pengumpulan data yang dibutuhkan untuk penelitian salah satunya adalah data tentang jumlah volume produksi UD. Cahaya Restu Kota Probolinggo tidak terlalu lengkap.

\section{Saran}

Dari hasil pembahasan di atas, maka saran yang dapat disampaikan adalah sebagai berikut :

1. Hendaknya Pihak UD. Cahaya Restu lebih meningkatkan jumlah persediaan bahan baku agar volume produksi akan terus meningkat dan memberikan pelatihan kepada karyawan agar dapat menghasilkan produk yang lebih bervariasi.

2. Bagi peneliti selanjutnya hendaknya menambah jumlah variabel lain (misalnya: kebutuhan modal, kondisi pasar, bahan ba- 
Dedi, Pengaruh Persediaan Bahan Baku dan Kapasitas Mesin Terhadap Produksi

kar atau tenaga kerja), sehingga

akan memperluas penelitian.

\section{DAFTAR PUSTAKA}

Astutik Ita Zuli. 2014. Pengaruh Jumlah Persediaan Bahan Baku, Kapasitas Mesin Dan Jumlah Tenaga Kerja Terhadap Volume Produksi Pada CV. Sanyu Paint Tropodo Sidoarjo. Jurnal Bisnis Indonesia Vol. 5 No.1 April 2014.

Handoko, T. Hani, 2000. Dasardasar Manajemen Produksi dan Operasi, Jilid II. BPFE Karta. Yogyakarta.

Karmini dan Istanti, 2016. Pengaruh Bahan Baku, Tenaga Kerja dan Investasi Terhadap Produksi Serta Ekspor
Keramik di Kabupaten

Tabanan. Jurnal EP Unud Vol. 5 No. 2 Februari 2016.

Ramdhani, A. 2014. Manajemen Operasi. Bandung: CV Pustaka Setia.

Santosa, Purbayu Budi. 2007. Statistik Deskriptif dalam Bidang Ekonomi dan Niaga. Jakarta: Erlangga.

Sudarmanto, Gunawan. 2005. Analisis Regresi Linear Ganda dengan SPSS. Yogyakarta: Graha Ilmu.

Supardi, 2005. Metode Penelitian Ekonomi dan Bisnis. Yogyakarta: UII Press.

Sofjan, Assauri. 2004. Manajemen Pemasaran. Jakarta: Rajawali Pres. 